\title{
Buying In: Positional Competition, Schools, Income Inequality, and Housing Consumption
}

\author{
Adam Goldstein, ${ }^{a}$ Orestes P. Hastings ${ }^{b}$
}

a) Princeton University; b) Colorado State University

Abstract: Social scientists have suggested that a key sociobehavioral consequence of rising inequality is intensifying market competition for advantageous positions in the opportunity structure, such as residences that afford access to high-quality public schools. We assess empirical implications of inequality-fueled positional competition theories (PCTs) by analyzing the relationships between metropolitan income inequality, households' efforts to secure residential positions in desirable school districts, and housing consumption behavior. We assemble a unique data set, which contains longitudinal information on household finances, residences, and geographic locations from the Panel Study of Income Dynamics; information on the quality of the school attendance areas in which these households reside; and information about the local real estate market. We find that greater inequality is associated with steeper housing price premia for residences in desirable areas, more pronounced social class sorting on school quality when relocating, and greater salience of schools relative to other housing amenities in families' housing expenditure functions. Families in high-inequality regions exhibit modestly greater willingness to pay more (relative to their own incomes) for a given improvement in school desirability. The analysis brings important empirical nuance to oft-invoked but untested theories about positional competition as a mechanism by which inequality affects behaviors, consumption, and markets.

Keywords: inequality; consumption; housing; positional competition; school attendance areas

Citation: Goldstein, Adam, and Orestes P. Hastings. 2019. "Buying In: Positional Competition, Schools, Income Inequality, and Housing Consumption." Sociological Science 6: 416-445.

Received: September 12, 2018

Accepted: March 22, 2019

Published: May 22, 2019

Editor(s): Jesper Sørensen, Kim Weeden

DOI: $10.15195 / \mathrm{v} 6 . \mathrm{a} 16$

Copyright: (C) 2019 The Author(s). This open-access article has been published under a Creative Commons Attribution License, which allows unrestricted use, distribution and reproduction, in any form, as long as the original author and source have been credited. (C) (i)
ROWING distributional inequality over the past four decades represents a signal $\exists$ transformation in American society, one that carries far-reaching implications for social behavior (Payne, Brown-Iannuzzi, and Hannay 2017). Despite extensive research and debate, the effects of widening inequality have proven rather elusive, in part because the underlying mechanisms are often left underspecified or untested (Neckerman and Torche 2007; Moss, Thaker, and Rudnick 2013).

One oft-theorized mechanism through which inequality is thought to shape behavior is by intensifying competition for positional assets (Frank 2007). The typically cited case is in public schools, which are accessed through the housing market and whose quality is a function of residential location. The fact that school attendance is coupled with neighborhood location makes residential choices a linchpin in parents' efforts to reproduce or advance the social class positions of their children (Lareau and Goyette 2014).

The positional competition thesis (PCT) suggests that as those at the top have captured a greater share of income, they have bid up the prices for the most advantageous positions, particularly residences in desirable neighborhoods with the best schools (Frank 2007). This has set off a cascading "arms race" whereby widening economic inequality leads to greater disparities between schools at the same time 
that it heightens the perceived necessity (and cost) of securing access to the best schools. The result is that parents feel compelled to increase their housing expenditures and mortgage debts to provide their children with the educational resources to compete in a society that they perceive to be increasingly winner take all. By this account, the sociobehavioral fallout of high inequality is manifested through increasingly costly competition for opportunity in the housing market. The fact that one must pay an ever greater price to access a constant relative level of school quality is what gives inequality its "teeth" (Grusky and MacLean 2016:44).

Variants of this argument have been articulated in several places (Frank 2007; Frank, Levine, and Dijk 2014; Charles and Lundy 2013; Bertrand and Morse 2016; Grusky and MacLean 2016; Fligstein, Hastings, and Goldstein 2017; Schneider, Hastings, and LaBriola 2018). However, there is surprisingly little research on the relationship between inequality and positional competition, and even less focuses on school attendance areas. Positional competition for schools is typically invoked as a mechanism rather than directly observed.

Our study assesses the empirical implications of inequality-fueled positional competition theories (Frank 2007) by analyzing the relationships between commuting zone (CZ) income inequality, households' efforts to secure residential positions in desirable school districts, and housing consumption behavior. We focus specifically on school attendance areas because we suspect they function as key structures linking inequality and housing market behavior. The U.S. public education system is marked by a high degree of inequality in resources and outcomes across schools, both between and within districts (Corcoran and Evans 2008; Logan, Minca, and Adar 2012). Despite the growth of various school-choice programs, attendance during the 2000s remained highly coupled with residential location (Lareau and Goyette 2014). In 2007, 82 percent of public-school students attended assigned neighborhood catchment schools, a decline of only 2 percent from 1996 (Grady and Bielick 2010).

We ask to what extent variations in income inequality across CZs drive intensified positional competition for schools within those regions as manifested in housing price premia across school attendance areas, in families' residential mobility behavior across school attendance areas, and in families' willingness to stretch themselves financially in order to upgrade school attendance areas. We then ask whether this positional competition for schools can help account for increasing housing expenditures among parents during recent decades.

If inequality intensifies competition for relative positions in the school distribution, we would expect that CZs with higher inequality would exhibit steeper housing cost premia and more rapid growth of premia between zip codes located in more or less desirable primary-school attendance zones. At the household level, we would expect that parents in higher-inequality regions would (1) exhibit a greater behavioral propensity to upgrade schools when moving. They will also (2) exhibit greater revealed willingness to stretch financially in order to gain or maintain a certain relative level of school quality and (3) weight school quality more heavily than nonpositional amenities, such as house size, in determining housing expenditure.

We empirically test these ideas by assembling a unique data set, which brings together longitudinal information on household finances, expenditures, and res- 
idential location (Survey Research Center 2015); indicators of the quality of the assigned primary schools in the census tracts where these households reside (School Attendance Boundary Information System [SABINS]); and zip-code-level information about local housing prices (Zillow 2014). Our analysis spans 1999 through 2011, a period that saw substantial growth in housing expenditure burdens for families.

Our analysis has three parts. We first assess the structural premises of the positional competition argument by examining the relationship between CZ-level inequality and school premia, which we define as the differential housing costs associated with a given rank increase in various school "quality" measures. We consider how these premia evolve over time across zip codes within CZs. We then use household-level panel data to track residential moves within CZs characterized by varying levels of inequality. Here we examine which households were most likely to engage in positional competition by moving to areas with more desirable schools and whether inequality heightens the relative weighting of school quality in households' residential choices. Finally, we examine the financial consequences of positional competition by assessing whether inequality heightens parents' willingness to stretch financially in order of the degree to which parents' efforts to secure access to higher-quality schools propelled growth in housing expenditures and mortgage debt-to-income ratios among families with school-age children. We further exploit variation between parents and nonparents and variation between areas with varying levels of public-school choice and/or private-school alternatives in order to assess whether school quality was an operative mechanism.

In addressing these questions, our project contributes to several social science literatures. Recent sociological research suggests that growing disparities between school districts have heightened the salience of perceived school quality in residential decision-making (Rivera and Lamont 2012; Goyette, Iceland, and Weininger 2014; Lareau and Goyette 2014; Weininger 2014; Owens 2016). We build on this line of research by modeling residential moves across school attendance areas, linking the schools-residence nexus to wider patterns of economic inequality, and considering the consequences of competition for schools on families' housing expenditure burdens.

Second, there is a sizable economic literature on the capitalization of school quality in housing prices (Black and Machin 2011), but this work has not examined how school price premia are related to variations in inequality across time and place. Nor has it considered how behavioral responses to growing school premia might vary across the social class spectrum.

Third, we contribute to a burgeoning literature on the relationship between inequality and consumption (Charles and Lundy 2013; Bertrand and Morse 2016; Schneider et al. 2018). Using cross-sectional data, prior work finds that higher levels of local inequality are associated with higher median consumption levels for a variety of goods, including housing and investments in children. By observing families' residential transitions across school attendance areas, we are able to gain greater empirical traction on a likely underlying mechanism.

Fourth, by documenting how behavioral responses to inequality heighten socioeconomic sorting of school quality, our analysis identifies a plausible mechanism 
linking metropolitan income inequality and reduced economic mobility (Chetty et al. 2014). We return to these themes in the discussion.

\section{Schools, Income Inequality, and Housing Prices}

Income inequality has been rising within the United States since at least the early 1980s (Piketty and Saez 2003). A number of scholars have suggested that this heightens "the stakes" (and anxieties) for parents who hope to provide their children with opportunities to succeed in a competitive, high-risk society (e.g., Nelson 2010). Parents may parent differently as a result, increasing how much time they spend with their children (Altintas 2016), increasing how much money they spend on their children (Kornrich and Furstenberg 2013; Kornrich 2016), and shifting how they allocate that money by increasing expenditures on educational "investments," such as lessons, tutoring, and extracurricular activities, that may provide advantages in the future (Schneider et al. 2018).

Some parents may seek to advantage their kids by enrolling them in private school (which is costly) or homeschool (which is time intensive). But, the vast majority of American parents utilize public schools (Murnane and Reardon 2018). Furthermore, in most regions, school attendance remains closely linked to residential location (Owens 2016). As noted above, during our study period, more than four-fifths of public-school students attended assigned catchment schools (Grady and Bielick 2010). Meanwhile, steadily declining private-school enrollment has diminished its significance as an alternative for middle-income households (Murnane and Reardon 2018), thereby tightening the link between residential location and school.

Given the coupling of residential location and school attendance-along with marked disparities between schools-it is not surprising that educational considerations loom large in families' residential decision-making (Lareau and Goyette 2014). Parents often choose to move to a locale specifically (or at least in part) to reside within the attendance area of a desirable school (Holme 2002; Kimelberg 2014; Lareau and Goyette 2014). Twenty-four percent of parents with school-age children report moving to their current neighborhood specifically for the schools (Grady and Bielick 2010:Table C-1).

The specific evaluative criteria and heuristics with which actors assess school quality are nuanced and variable across groups and contexts (e.g., Johnson and Shapiro 2003; Dougherty et al. 2009). Some research suggests that they tend to rely on evaluative shortcuts, such as reputational status, information from alters, or the economic and racial composition of students, rather than in-depth research on variations in school programs or outcomes (Holme 2002; Goyette, Farrie, and Freely 2012; Billingham and Hunt 2016; Rich 2017). However, others suggest that the recent incorporation of test-score ratings into real estate search engines, such as Zillow, could tighten the link between test scores and housing choices (Weininger 2014).

Notwithstanding variation in how parents construct perceptions of "good schools," these perceptions matter insofar as they play a consequential roll in residential outcomes at both the micro and macro levels (Holme 2002; Kimelberg 
2014; Goyette et al. 2014; Lareau and Goyette 2014). For instance, Owens (2016) points out that increases in residential income segregation since 1990 are driven solely by families with children, a fact that she suggests is attributable to increasing competition for desirable schools (but see Logan et al. 2018). ${ }^{1}$

The connection between schools and housing is also evident in prices. Housing economists have long studied demand for desirable schools by examining the relationship between various quality metrics and housing prices (e.g., Black 1999; Clapp, Nanda, and Ross 2008). Hedonic price models treat schools as a residential amenity. Parents' willingness to pay for better schools is reflected, or capitalized, in higher house prices. Because economic studies tend to be interested in the marginal causal effect of schools on prices, they typically focus on individual cities and use spatial discontinuity designs. Most studies estimate the school premium to be somewhere on the order of 2 percent to 10 percent for a one-standard deviation increase in a given school quality metric (Black and Machin 2011).

Although economists have devoted significant attention to quantifying the effect of school quality on house prices, very little research has considered how these premia vary across cities or over time amid widening inequality. This gap is important because the argument that positional competition for schools drove growing expenditures presumes that the relative premium for moving up the school rank distribution grew larger over time, thereby forcing families to take on ever more expenditure burden in order to attain a given school quality.

Meanwhile, studies of inequality and housing expenditures have shown that greater inequality in states and metropolitan areas tends to be associated with greater median spending on housing within those areas (Charles and Lundy 2013; Bertrand and Morse 2016). Although researchers have speculated that this association is driven partly by competition for schools, a lack of microgeographic data has prevented studies from linking expenditure burdens explicitly to the intrametropolitan geography of educational resources.

\section{Hypotheses}

The basic claim of PCT is that greater inequality heightens the stakes of positional location, thereby increasing the salience of perceived school quality in residential decision-making and intensifying competition for the best positions in the school distribution. For example, greater inequality may prompt more parents to seek access to the very best schools by triggering anxiety about class reproduction in an increasingly winner-take-all society (Frank 2007; Nelson 2010; Schneider et al. 2018). Furthermore, it might also encourage social comparison processes (Charles and Lundy 2013) or make more visible the costs of failing to attain a relatively desirable position. Hence, even as inequality increases the cost of upgrading, it also heightens the impetus to do so.

These arguments carry implications that we should to be able to observe at both the area and household levels. Below, we elaborate on eight hypotheses across three sets of outcomes.

At the aggregate level, we expect that greater inequality would be associated with larger housing price premia for top schools, both because inequality heightens 
overall demand for advantageous positions in the opportunity structure (Grusky and MacLean 2016) and because a more unequal distribution of resources means that wealthier families have more capacity to bid up the housing prices in the best areas (Frank 2007; Charles and Lundy 2013). It follows that regions with higher inequality should exhibit steeper gradients of housing cost premia between zip codes located in more or less desirable school attendance zones as well as more rapid growth of these premia over time.

Hypothesis 1: The housing price premia for desirable school attendance areas was greater in higher-inequality areas.

Hypothesis 2: Housing price premia for desirable school attendance areas grew relatively larger between 1999 and 2011 in higher-inequality areas.

At the household level, we can ask to what extent parents were actively participating in the positional competition by relocating into better school attendance areas. If contextual inequality increases the salience of perceived school quality in residential decision-making, then ceteris paribus, efforts to upgrade school quality will tend to play a greater role in structuring patterns of residential relocation among families in high-inequality areas compared to those in lower-inequality areas. Despite the greater cost, parents will work to ensure that moves maintain or improve school quality, whereas movements of otherwise similar families in lower-inequality areas will be less structured by relative differences in school rank because those differences do not carry the same stakes.

Hypothesis 3: When moving, families are more like to upgrade or avoid downgrading in the desirability of their school attendance zones in more unequal areas relative to those in less unequal areas.

Of course, neither the relative weighting of schools in locational decisions nor the ability to afford upgrades will be evenly distributed across social groups and contexts. As suggested by Frank (2007), upper-middle-income households will engage most directly in positional competition because they are most directly subject to social comparison pressures to keep up with those at the top and also because they have the financial resources to compete. Compared with lower-income families, they are also more likely to be homeowners, which means they can move purposively rather than reactively in response to rent pressures. Lower-income movers often cannot afford to let schools dictate location (Rhodes and DeLuca 2014).

We would expect social class differentials in school mobility to be particularly pronounced in high-inequality areas because of affordability constraints. Given a nonmonotonic school premium gradient in higher-inequality areas, lowersocioeconomic status (SES) households will be less able to afford any meaningful upgrades in high-inequality areas. Only families in upper- and upper-middle-SES positions will have both the wherewithal and resources to even play the school maximization game. In other words, inequality heightens the degree to which we will observe social sorting on the basis of school quality. This implies a positive interaction effect between contextual inequality and family SES on upward mobility into more desirable school attendance areas. 
Hypothesis 4: When moving, higher-SES parents are more likely to upgrade (or avoid downgrading) the desirability of their school attendance zones, particularly in higher-inequality CZs.

Because areas with higher-performing schools are probably desirable places in other respects as well (e.g., lower crime and more retail amenities), school performance will be confounded with other attributes (Bruch and Mare 2001:11). To the extent that positional competition for school quality is an operative mechanism driving observed premia and housing expenditures, the effects should be weaker in areas with more public-school choice because of looser coupling between residential location and available school options. We expect that the association between assigned-school desirability and both school price premia and housing expenditures should be weaker in districts where a greater proportion of students attend nonneighborhood charter or magnet schools.

Hypothesis 5: Greater school choice diminishes the likelihood that families will upgrade when moving.

Next, we can consider the household financial consequences of the positional competition for schools. Above, we hypothesized that as competition for housing in better school attendance areas increases, the housing price premia would increase as well. For families to compete, it may then become necessary to stretch further financially.

Parents will not only feel compelled to live near a better school but will also take on ever greater expenditure burdens in order to make the move possible. In the aggregate, our period of study saw substantial growth in housing expenditure burdens among families with children. Real housing expenditures grew between 21 percent and 31 percent across all five household income quintiles (author's calculation from Consumer Expenditures Survey). By 2006, 47 percent of renters and 36 percent of mortgaged homeowners had monthly housing costs that exceeded the conventional 30 percent of income affordability cutoff (Schwartz and Wilson 2008). Despite flattening after the housing bubble burst in 2007, housing expenditure levels remained elevated after the recession of 2008 to 2009. The inequality-fueled PCT implies that intensifying efforts to attain desirable schools contributed to this expenditure growth.

Hypothesis 6: Inequality heightens the willingness of families to increase their housing expenditures when upgrading in school attendance areas.

However, as noted above, desirable schools are closely correlated with a number of desirable characteristics of areas. To see if schools are really a key part of the mechanism driving increasing housing expenditures, we can compare parents and nonparents. If parents are expending and leveraging more than nonparents to access a given school quality, then we can be more confident about the mechanism.

Hypothesis 7: Parents increase their housing expenditures more than nonparents for the same amount of change in school-area desirability. 
Finally, to test whether greater inequality makes school ranking more salient, we can compare the relative weighting of schools in households' latent demand function. If parents are stretching themselves financially specifically in order to maximize school quality as inequality grows, then we would expect them to be economizing on other housing attributes, such as absolute size. We can use a parametrically weighted regression model (Yamaguchi 2002; Buis 2012) to test whether the relative weighting of schools versus nonpositional amenities, such as house size, varies across levels of $\mathrm{CZ}$ inequality.

Hypothesis 8: As inequality increases, the interaction between inequality and schools grows proportionately greater than the interaction between inequality and housing unit size.

Before turning to a discussion of methods, it is worth clarifying that the hypotheses above represent separate empirical implications of the PCT (Lieberson and Horwich 2008), none of which are logically dependent upon the others. For instance, an alternative hypothesis suggests that the school price premium did grow, but this growth did not propel a corresponding rise in housing expenditure burdens because the highest-income households were sorting into the places with the best schools. We know that residential income segregation has grown across cities and across school districts since the 1980s (Reardon and Bischoff 2011; Owens, Reardon, and Jencks 2014). A countervailing effect of income sorting may have mitigated any effects of positional competition for schools on housing consumption if those who were seeking top schools could afford to buy into such areas without taking on disproportionate amounts of leverage or expenditure burden. ${ }^{2}$ Similarly, another weak form of PCT suggests that school premia did not grow over time, even in highinequality areas. Instead, housing prices grew proportionately across the school distribution for exogenous reasons. But because parents of a given socioeconomic class position expect a certain level of schooling for their children, they are willing to take on greater expenditures in order to upgrade or maintain a constant position. In short, we test all of the hypotheses above, but it is plausible that some will be supported, but others will not. All hypotheses and outcomes are summarized at the end of the results section.

\section{Data and Methods}

To test these hypotheses, we assemble a unique data set that brings together longitudinal information on household finances, expenditures, and residential location (Panel Study of Income Dynamics [PSID]); indicators of the quality of the assigned elementary schools in the census tracts where these households reside (SABINS); and zip-code-level information about local housing prices (Zillow 2014). Whereas most prior research on school-housing linkages utilizes granular parcel data from a single city, we are interested in how competition for schools varies across metropolitan regions with differing levels of inequality. This involves overlaying multiple types of geographic data, some of which are based on nonnested geographies and/or reported at differing levels of granularity across administrative agencies. 
Our approach thus involves some degree of trade-off between comprehensiveness and spatial measurement precision.

We begin by obtaining two measures of school desirability: Our main measure is a school-level percentile rank measure based on standardized test scores. The ranking is based on the percentage of third, fourth, and fifth graders proficient in mathematics, which is normalized within each state to account for different testing regimens. For robustness, we also consider the school-level proportion of students not eligible for reduced-price lunch. Use of multiple measures makes the study less indicator dependent, and it accords with the mixed findings on parents' evaluation of potential schools. The test-score data represent a salient output, one of which could shape reputations and is incorporated into various school rankings. The reduced-price-lunch measure partially captures the portion of poor students within the school (although see Domina et al. 2018), something that parents may consider in determining their school preference. School data come from the Department of Education's Common Core of Data and the National Longitudinal School-Level State Assessment Score Database.

We then linked the measures of school desirability to each census tract using a geographic crosswalk (based on 2008 school areas linked to 2010 census tracts from SABINS) between school attendance zones and census tracts. School attendance areas are not neatly nested within tracts. In cases in which tracts contain multiple primary-school attendance areas, we took a block-weighted mean of the school desirability measures. For tracts where school-level attendance-area locators were unavailable, we linked to district-level attendance areas and calculated districtlevel measures. This approach does induce some measurement error insofar as attendance areas might have changed between 1999 and 2008. Because comparable test-score data were not consistently available in most states before 2008, we treat this measure as a time-constant feature within tracts.

Finally, in ancillary analyses, we gauged variations in the strength of coupling between residential location and school attendance using a district-level measure of public-school choice. We measure choice using the proportion of students enrolled in nonneighborhood charter or magnet schools. We caution that this measure is an imperfect proxy because it fails to capture several forms of intra- and interdistrict open enrollment policies, which allow students to attend schools outside of their assigned catchment zone. Unfortunately, there are no available systematic data on such programs.

To examine school premia (i.e., the relationship between school desirability and housing prices), we merge data on the annual median zip-code price for 1999 through 2011 (Zillow 2014) with the school desirability data. Then, to examine how income inequality moderates this relationship, we use the Gini index of income inequality at the commuting-zone level.

Commuting zones are aggregations of counties designed to capture local labor markets (Tolbert and Sizer 1996; Autor and Dorn 2013). These data are based on the nontop-coded Internal Revenue Service tax returns from 1996 to 2000 of families with children (Chetty et al. 2014). We avoid simultaneity bias by using a measure of income inequality that predates our outcome measures. CZs are ideal for our analysis because they are specifically constructed to encompass areas where people 
work. In other words, one could conceivable live anywhere within a commuting zone and maintain the same job, but where they live within the $\mathrm{CZ}$ would have important implications for where their children attended school.

Building from the housing price analysis, we then examine families' moves across school attendance zones and the financial consequences of those moves. We do this by using household-level data from the 1999-to-2011 PSID, which provides biennial observations on residential transitions, housing expenditures, and mortgage debt for approximately 8,500 families. We use the restricted-use version of the PSID data, which contains geographic locators at the census-tract level. This allows us to track household moves across school attendance areas. School-level attendance zone data were available for about 60 percent of the PSID sample, and for the remaining 40 percent, we link tracts to district-level boundaries and calculate school quality measures as the weighted average of primary schools within the district. To maintain comparability between households with and without children, we limit this analysis to households for which the head of household is under age 65. To gauge the socioeconomic status of households, we construct a summary SES index from a principle components analysis of total family income and highest educational attainment of either the head or spouse.

For our models of mobility across school attendance areas, we use the move as the unit of analysis and specify a first difference model (also known as a conditional change score model). The model estimates the conditional expected change in the quality of the assigned school between the old and new residence among movers with children under age 18, controlling for quality of the assigned school at the old residence. Because the likelihood of moving in the first place is not independent of our covariates of interest, we implemented a two-stage Heckman sample correction (1976), using the inverse Mills ratio. Standard errors are clustered at the family level because some families move multiple times. We confine the sample to local moves within CZs in order to distinguish contextual effects of inequality from the effects of moving to a different context (Sampson 2008). We observed 4,617 intra-CZ moves among families with children.

In the third stage of the analysis, we turn to families' willingness to increase their housing expenditure burdens in order to attain better schools. We operationalized housing expenditures, which include mortgage and loan payments, rent, property tax, insurance, and utilities, as (1) the ratio of housing expenditures to total family income and (2) logged housing expenditures (when using this measure, we control for income). Because expenditures can change without moving residences, we use household-year as the unit of analysis and estimate fixed-effects models. As in the move-level analysis discussed above, for the reported models, we restrict the analytical sample to households that remain within a single CZ during the study period. This allows us to estimate the contextual effect of inequality on willingness to pay for upgrades when moving across school attendance areas within a CZ. We first examine parents only and then consider how the results differ for parents and nonparents. All of these models include a large number of household-level controls (listed in the respective footnotes of Tables 1, 2, and 3).

Before turning to the results, it is useful to discuss some potential pitfalls of our geographic linkage and the implications for our analysis. First, limited geographic 
coverage in the SABINS means that school-level geographic linkages are only available for a subset ( $\sim 60$ percent) of the PSID analytical sample observations. For the other 40 percent, we use district-level average desirability measures. Thus, school desirability is captured with varying degrees of measurement error. To ensure that differences between these groups do not bias the results, we replicated the analyses using only the subsample for whom school-level locators were available. We found very a similar pattern of results (see the online supplement). ${ }^{3}$

Second, when SABINS linkages are available, multiple elementary-school attendance areas can span a given census tract. Our inability to distinguish PSID respondents' assigned school within multischool census tracts will produce only modest measurement error for the simple reason that schools that span a common census tract tend to be highly correlated in terms of desirability measures. We conducted a variance decomposition using block-level data and found that across all 2,871,485 census blocks with SABINS school-attendance linkages, 87 percent of the total variance in math test-score proficiency is between tracts, and 95 percent of the variance in the proportion of students eligible for reduced-price lunch is between tracts. Among those tracts with multiple school attendance areas, the average within-tract standard deviation in proficiency scores across block groups is 3.8 percentage points (out of 100 ).

Within-unit heterogeneity is more pronounced in our analysis of the relationship between school desirability and zip-code median housing prices: 74 percent of the total variance in assigned-school test scores at the census-block level is between zip codes, and 84 percent of the variance in reduced-price-lunch eligibility is between zip codes. This aggregation is unavoidable given that there is no reliable housing price data with national coverage at sub-zip level.

Finally, one might be concerned that the amount of unmeasured within-area heterogeneity is correlated with our key contextual covariate: metropolitan inequality. This could lead to biased estimates in both the housing-price and household analyses. Such bias is plausible insofar as one might expect that regions with greater inequality will tend to be characterized by more fractured and variable sociospatial geography. We checked this and found that, in fact, CZ inequality (Gini) is almost entirely uncorrelated with the mean number of school areas that overlap a given tract $(\mathrm{r}=-0.12)$ and with intratract variation in block-level assigned-school test scores $(\mathrm{r}=-0.01)$.

\section{Results}

\section{Schools, Inequality, and Housing Prices}

Our first analyses concern the relationships between neighborhood housing-price differentials, local school desirability, and CZ-level income inequality. Figure 1 shows patterns of real housing prices at the zip-code level using the school testscore metric. The estimates in Figure 1 are derived from simple regression models in which each zip-code year observation is centered within commuting zones. The differences between school proficiency deciles can be interpreted as the average price differential relative to other zip codes in the same commuting zone. Each 

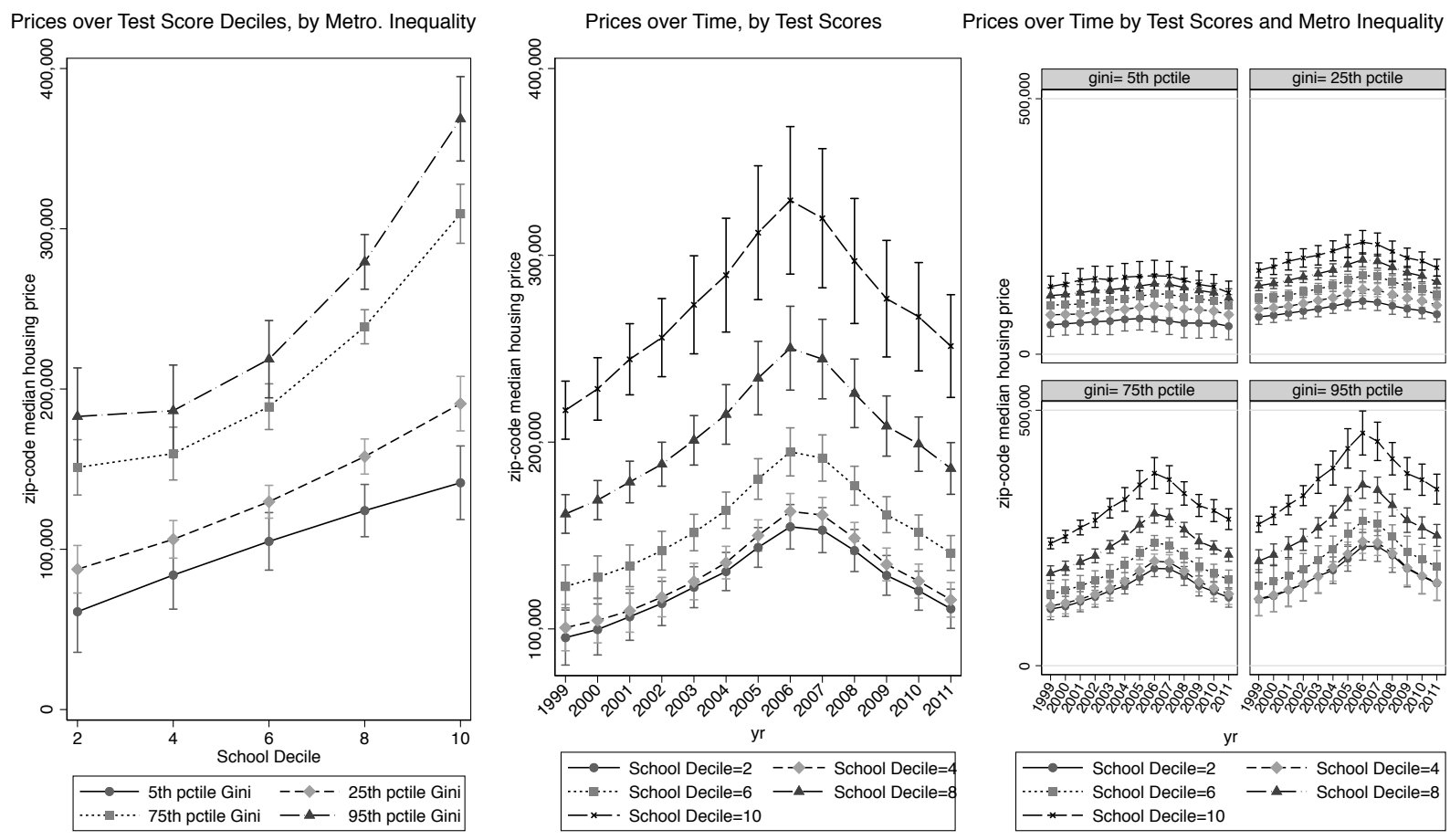

Figure 1: Housing prices by level of test-score decile, income inequality, and year.

model includes a quadratic term for school decile, and the effects of inequality are allowed to vary across time- and school-decile levels. Predicted prices are then calculated from the estimates and presented in Figure 1.

Panel A Figure 1 shows that, consistent with Hypothesis 1, the gradient of the school premium tends to be steeper in CZs with higher inequality (pooled over the study period). However, contrary to Hypothesis 2, the average school premium evidences little growth over time, as seen in panel B.

Panel $\mathrm{C}$ of Figure 1 shows estimates with three-way interactions between year dummies, school deciles, and $\mathrm{CZ}$ income inequality. The relative invariance in school premia over time holds across varying levels of $\mathrm{CZ}$ inequality. Even in high-inequality areas, the school premium did not grow wider because prices in neighborhoods with lower-performing schools also changed at a rapid rate in highinequality CZs. For instance, at the 95th percentile of CZ inequality, zip codes with schools at the fourth decile of school performance saw real housing prices grow by 86 percent from 1999 to the market peak in 2006, whereas those at the top decile of the school quality distribution saw median prices increase by 64 percent over the same period.

We obtain very similar results when we use the proportion eligible for school lunch as an alternative measure of school desirability (not shown). We also obtain similar results if we calculate the simple cell means rather than regression estimates of the within-CZ premia. 
Taken together, patterns of housing price growth across school attendance areas reveal a nuanced story, which is only partly consistent with the positional competition argument. Higher-inequality CZs do exhibit higher median housing prices on average, more rapid over-time change in median housing prices, and steeper school premium gradients on average. Practically, this means that the relative premium families must pay to access zip codes with top schools is greater in higher-inequality CZs, and the absolute cost to access higher-ranked schools does increase to a significantly greater extent for those who reside in higher-inequality areas compared with those who reside in lower-inequality areas. However, it is important to emphasize that we find little evidence of widening school premia within CZs over time, even in the highest-inequality CZs. In other words, greater income inequality circa 1999 is not associated with increasing relative cost to access the top schools over the following 12 years (because housing costs in zip codes with lower-ranked schools also change at a comparable rate). The fact that we do not observe a widening premium for top schools in high-inequality areas casts some doubt on the theory that inequality-fueled positional competition for schools played a direct role in causing the rapid growth of housing prices in high-inequality CZs.

\section{Residential Moves across School Attendance Areas}

Which families experience upward school mobility when moving across census tracts, and how is this shaped by variations in CZ income inequality?

Table 1 shows the results of the first difference models of change in school desirability, using the school test-score percentile rank as a measure of desirability. Here the unit of analysis is the move, and the outcome is measured as the withinfamily change in assigned-school desirability, conditional on moving within a $\mathrm{CZ}$. Because the likelihood of moving in the first place is not independent of our covariates of interest, we estimated a two-stage selection model (Heckman 1976). Identical specifications using the free- or reduced-price-lunch eligibility measure are shown in the online supplement.

Hypothesis 3 predicted that, among families, moves in higher-inequality areas will be more consistently structured so as to upgrade school quality. As seen in models 1 through 3, we find no evidence of any overall effect of contextual inequality on parents' likelihood of improving schools when they move.

We do find that mobility across school attendance zones during this period was highly graded by socioeconomic status. When they move within CZs, higherSES families tended to upgrade assigned schools by a full decile relative to their previous school location, whereas families in middle- and lower-SES quintiles tended to move laterally. This differential response is not entirely surprising given that lower- and middle-SES families are more likely to be moving under conditions of financial duress, eviction, or other unplanned circumstances, all of which make upgrading difficult. However, as seen in model 3, the conditional difference persists even when controlling for the reported reason why the household moved. This class-stratified pattern of upgrading versus downgrading school attendance areas is consistent with the idea that competition for schools positively affects residential 
Table 1: Estimates from two-stage first difference models of change in families' assigned school percentile rank.

\begin{tabular}{|c|c|c|c|c|c|c|}
\hline & \multicolumn{6}{|c|}{$\Delta$ School Rank Percentile } \\
\hline & (1) & (2) & (3) & (4) & (5) & (6) \\
\hline Previous school rank & $\begin{array}{r}-0.301^{*} \\
(0.016)\end{array}$ & $\begin{array}{r}-0.312^{*} \\
(0.016)\end{array}$ & $\begin{array}{r}-0.316^{*} \\
(0.016)\end{array}$ & $\begin{array}{r}-0.302^{*} \\
(0.016)\end{array}$ & $\begin{array}{r}-0.313^{*} \\
(0.016)\end{array}$ & $\begin{array}{r}-0.335^{*} \\
(0.012)\end{array}$ \\
\hline $\mathrm{CZ}$ inequality (gini) & $\begin{array}{c}0.489 \\
(5.005)\end{array}$ & $\begin{array}{c}6.099 \\
(4.929)\end{array}$ & $\begin{array}{c}5.571 \\
(5.071)\end{array}$ & $\begin{array}{r}-10.07 \\
(9.086)\end{array}$ & $\begin{array}{r}-5.782 \\
(8.888)\end{array}$ & $\begin{array}{r}-3.724 \\
(6.304)\end{array}$ \\
\hline Second SES Quintile & $\begin{array}{c}0.951 \\
(1.009)\end{array}$ & $\begin{array}{c}0.123 \\
(1.009)\end{array}$ & $\begin{array}{c}0.302 \\
(1.030)\end{array}$ & $\begin{array}{r}0.0641 \\
(6.382)\end{array}$ & $\begin{array}{c}-1.294 \\
(6.358)\end{array}$ & $\begin{array}{c}1.279 \\
(4.684)\end{array}$ \\
\hline Third SES Quintile & $\begin{array}{c}2.406^{*} \\
(1.140)\end{array}$ & $\begin{array}{c}1.074 \\
(1.157)\end{array}$ & $\begin{array}{c}1.012 \\
(1.189)\end{array}$ & $\begin{array}{r}-3.970 \\
(6.285)\end{array}$ & $\begin{array}{c}-4.988 \\
(6.138)\end{array}$ & $\begin{array}{c}-2.831 \\
(4.693)\end{array}$ \\
\hline Fourth SES Quintile & $\begin{array}{r}4.968^{*} \\
(1.334)\end{array}$ & $\begin{array}{c}3.254^{*} \\
(1.309)\end{array}$ & $\begin{array}{c}3.448^{*} \\
(1.348)\end{array}$ & $\begin{array}{r}-3.677 \\
(7.198)\end{array}$ & $\begin{array}{c}-7.627 \\
(7.042)\end{array}$ & $\begin{array}{c}-4.582 \\
(5.973)\end{array}$ \\
\hline Top SES Quintile & $\begin{array}{c}8.948^{*} \\
(1.481)\end{array}$ & $\begin{array}{r}6.637^{*} \\
(1.479)\end{array}$ & $\begin{array}{c}6.853^{*} \\
(1.531)\end{array}$ & $\begin{array}{c}-6.944 \\
(7.560)\end{array}$ & $\begin{array}{r}-10.87 \\
(7.641)\end{array}$ & $\begin{array}{r}-6.034 \\
(6.251)\end{array}$ \\
\hline Own-to-own Move & & $\begin{array}{r}6.910^{*} \\
(1.595)\end{array}$ & $\begin{array}{r}7.517^{*} \\
(1.643)\end{array}$ & & $\begin{array}{c}6.999^{*} \\
(1.595)\end{array}$ & $\begin{array}{r}6.616^{*} \\
(1.161)\end{array}$ \\
\hline Rent-to-own Move & & $\begin{array}{c}1.864 \\
(1.538)\end{array}$ & $\begin{array}{c}2.548 \\
(1.689)\end{array}$ & & $\begin{array}{c}1.714 \\
(1.540)\end{array}$ & $\begin{array}{r}2.964^{*} \\
(1.174)\end{array}$ \\
\hline Own-to-rent Move & & $\begin{array}{c}1.488 \\
(1.607)\end{array}$ & $\begin{array}{c}1.084 \\
(1.654)\end{array}$ & & $\begin{array}{c}1.492 \\
(1.598)\end{array}$ & $\begin{array}{c}2.389 \\
(1.227)\end{array}$ \\
\hline Second SES x Inequality & & & & $\begin{array}{r}1.658 \\
(13.82)\end{array}$ & $\begin{array}{r}2.809 \\
(13.79)\end{array}$ & $\begin{array}{r}-2.846 \\
(9.832)\end{array}$ \\
\hline Third SES x Inequality & & & & $\begin{array}{c}13.67 \\
(13.65)\end{array}$ & $\begin{array}{c}12.96 \\
(13.26)\end{array}$ & $\begin{array}{c}7.505 \\
(9.795)\end{array}$ \\
\hline Fourth SES x Inequality & & & & $\begin{array}{c}18.45 \\
(15.59)\end{array}$ & $\begin{array}{c}23.19 \\
(15.04)\end{array}$ & $\begin{array}{c}15.52 \\
(12.43)\end{array}$ \\
\hline Top SES x Inequality & & & & $\begin{array}{c}32.98^{*} \\
(15.85)\end{array}$ & $\begin{array}{c}36.24^{*} \\
(15.88)\end{array}$ & $\begin{array}{l}29.56^{*} \\
(12.86)\end{array}$ \\
\hline \% School Choice & & & & & & $\begin{array}{c}-22.01^{*} \\
\quad(5.348)\end{array}$ \\
\hline Second SES x School Choice & & & & & & $\begin{array}{c}0.101 \\
(8.364)\end{array}$ \\
\hline Third SES x School Choice & & & & & & $\begin{array}{l}17.60 \\
(9.680)\end{array}$ \\
\hline Fourth SES x School Choice & & & & & & $\begin{array}{c}21.51 \\
(11.55)\end{array}$ \\
\hline Top SES x School Choice & & & & & & $\begin{array}{c}-13.01 \\
(16.46)\end{array}$ \\
\hline Constant & $\begin{array}{c}8.941^{*} \\
(2.581)\end{array}$ & $\begin{array}{l}11.53^{*} \\
(2.601)\end{array}$ & $\begin{array}{r}-47.49^{*} \\
(3.035)\end{array}$ & $\begin{array}{l}13.86^{*} \\
(4.270)\end{array}$ & $\begin{array}{l}17.08^{*} \\
(4.231)\end{array}$ & $\begin{array}{l}17.90^{*} \\
(3.187)\end{array}$ \\
\hline Additional Controls & No & Yes & Yes & No & Yes & Yes \\
\hline Reported Reason for Moving & No & No & Yes & No & No & No \\
\hline Observations & 15,480 & 15,480 & 15,316 & 15,480 & 15,480 & 15,480 \\
\hline
\end{tabular}

Standard errors are in parentheses. Model is estimated from within-CZ moves among families with children from 1999 to 2011. All models employ survey weights. Additional demographic control variables include marital status, household size, and age of youngest child. First-stage selection equation estimates are not shown. ${ }^{*} p<0.05$ 
income segregation among families with children during this period (Owens 2016; but see Logan et al. 2018).

Models 4 and 5 add the interaction term between inequality and SES. Consistent with Hypothesis 4, greater inequality does appear to heighten the salience of school desirability in locational changes but only among upper-SES families. Figure 2 illustrates this by plotting estimates from model 5 at the 25th and 75th percentiles of CZ inequality. Top-SES-quintile families who move within higher-inequality CZs tend to upgrade assigned schools (relative to their previous zip code) by a factor twice as great as high-SES movers in lower-inequality CZs and lower-SES households in high-inequality CZs. In other words, greater inequality heightens the impetus for higher-SES families to move up, thereby amplifying social class sorting on school desirability among families when moving.

We find very similar results when using the alternative measure of school desirability (percentage of students not eligible for reduced-price lunch), which is reported in the online supplement. The same basic pattern also appears if we expand the sample to include between-CZ moves, though in this case, the interpretation of the inequality effect is less clear. Finally, the above models use a measure of school quality that is normalized within states. The lower mobility in low-inequality CZs could simply reflect the more limited distribution of school ranks in those areashence a more limited range of opportunities to move up or down. To ensure that such variations are not driving the results, we reran the models using CZ-centered versions of the school test-score rank. This approach yielded substantively similar results.

To further assess whether schools per se are driving residential mobility across school attendance areas, we next turn to Hypothesis 5 by reexamining mobility patterns across CZs with varying levels of school choice. Column 6 of Table 1 shows the specification in which we add an interaction between SES and school choice, controlling for inequality. The bottom panel of Figure 2 plots predictions from this model. When greater choice loosens the coupling between schools and residential location, families are less prone to move to zip codes with better assigned schools compared with families who are moving in CZs with less choice. This result is consistent with Hypothesis 5, and it lends credibility to the idea that competition for schools (rather than other unobserved neighborhood characteristics) is a key mechanism in driving mobility across more or less desirable school attendance areas.

However, as seen in Figure 2, this association between heightened choice and diminished upgrading is confined to families in the bottom 40 percent and in the top 20 percent of the parental SES distribution. These families tend to upgrade by four to seven fewer percentile ranks when they are moving within CZs with high levels (90th percentile) of school-choice availability compared with movers in CZs with zero nonneighborhood schools. In contrast, for families in the 40th to 80th SES percentiles, greater availability of nonneighborhood charter or magnet schools has little apparent impact on locational decisions when moving. This might reflect the particular appeal of charters and magnets for high- and low-SES families living in urban cores, where these types of schools are most prevalent. 

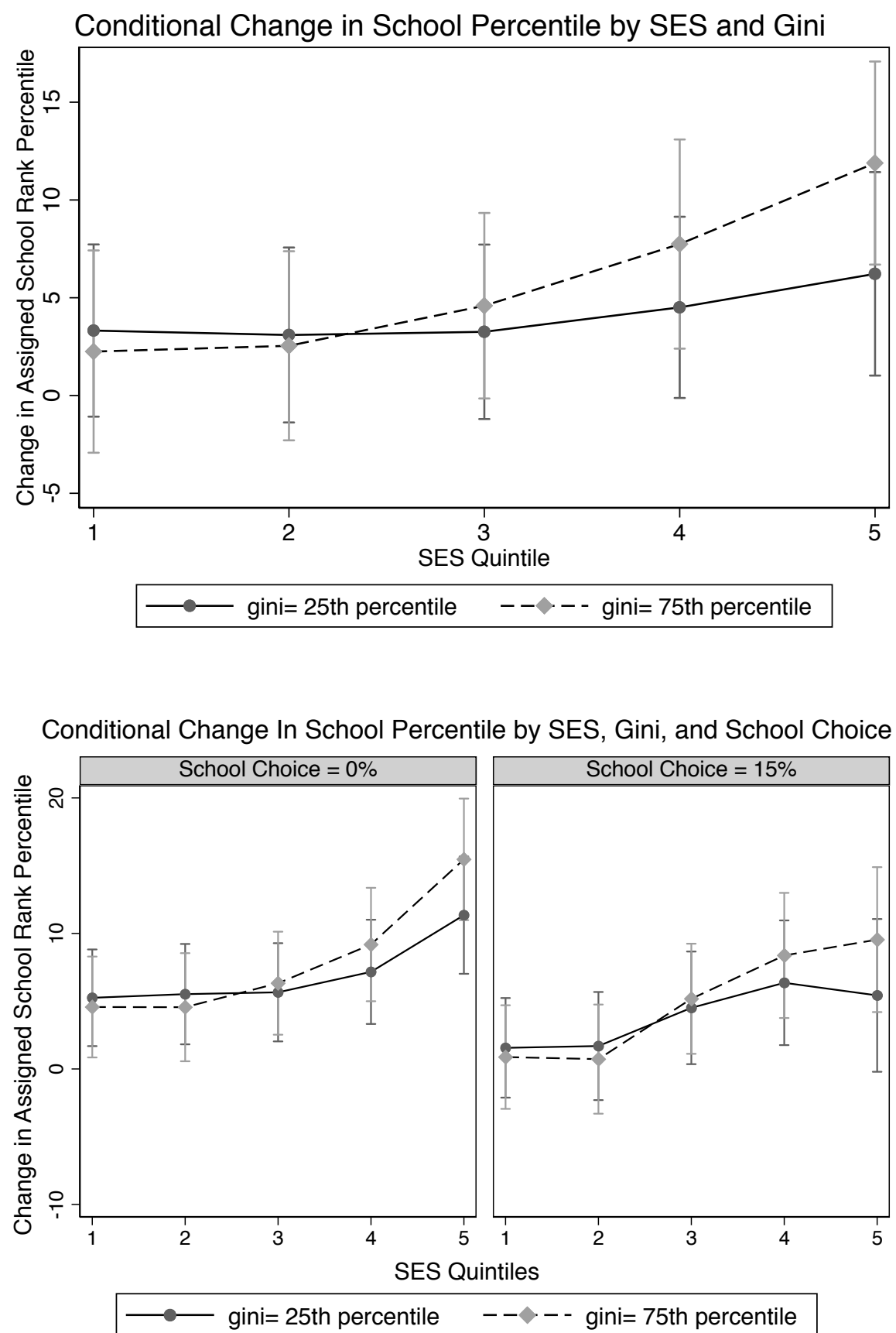

Figure 2: Model predictions of assigned-school test-score rank mobility among families who move within commuting zones at the 10th and 90th percentiles of income inequality, with all control variables being held at their means (top panel) and when including an interaction between family SES and percent school choice (bottom panel). 
Substantively, the results in Figure 2 imply that greater choice does modestly diminish the intensity of positional competition in the housing market but in a subtle, class-differentiated manner. Prior work has found that higher-SES families are able to take advantage of school-choice programs to a greater degree than lower-SES families because they face fewer constraints on moving their children to different schools (Rich and Jennings 2015). The results in Figure 2 offer some suggestive evidence that the availability of magnet schools can also disproportionately benefit top-quintile families by allowing them to arbitrage looser school-neighborhood coupling in their residential decision-making (Weininger 2014).

In sum, regardless of the primary stated reason why they moved, top-SESquintile families tended to move up to better schools, whereas lower-SES families tended to move laterally. This sorting was particularly marked in higher-inequality $\mathrm{CZs}$, where top-quintile families were especially likely to upgrade schools despite the high absolute cost, and it was somewhat mitigated in regions with greater availability of nonneighborhood schools. Taken together, these results are consistent with the expectation that higher-SES families will engage most directly in positional competition for desirable school districts and that greater local inequality will heighten the degree to which school desirability structures their residential movements. Middle- and lower-quintile families are largely priced out of the competition for schools (Fligstein et al. 2017).

\section{Household-Level Financial Consequences of Positional Competition}

For the third set of analyses, we move the school quality measures to the right side of the equation. Here we consider first whether families' efforts to position themselves in more desirable school attendance areas contribute to the growth of housing expenditures, as predicted by Frank (2007) and others. We then ask whether inequality heightens their willingness to stretch financially in order to access better schools.

Table 2 presents the fixed-effects models for each expenditure outcome and for each measure of school desirability. Models 1 and 3 use only the sample of families with children. In each of these models, the coefficient of school desirability is positive and statistically significant, meaning that, all else being equal, families took on greater housing expenditures when moving to access better schools. For example, model 3 suggests that a one-decile increase in the math score rank of a school is associated with about a 1.2-percent increase in housing expenditures. A 0.1-decile increase in the proportion of students not eligible for reduced-price lunch is associated with about a 3.2-percent increase in housing expenditures. These patterns are consistent with Hypothesis 6, though we note that the magnitudes are rather small.

In additional specifications, we relaxed the assumption of equal expenditure elasticities across the social class spectrum by adding the interactions between SES and school desirability. There is no consistent pattern of social class differences across any of the various measures of housing expenditure. Although higher-SES households are more likely to upgrade than lower-SES families, the financial effect of a given one-decile increase in the housing-expenditure-to-income ratio is no 
Table 2: Estimates from fixed-effects models of PSID respondents' housing expenditures.

\begin{tabular}{|c|c|c|c|c|}
\hline \multirow[b]{3}{*}{ math score rank } & (1) & $(2)$ & (3) & $(4)$ \\
\hline & \multicolumn{2}{|c|}{$\begin{array}{c}\text { housing } \\
\text { expenditure-to-income } \\
\text { ratio }\end{array}$} & \multicolumn{2}{|c|}{$\begin{array}{l}\log (\text { housing } \\
\text { expenditure) }\end{array}$} \\
\hline & $\begin{array}{c}0.002 \\
(0.002)\end{array}$ & $\begin{array}{c}0.003 \\
(0.002)\end{array}$ & $\begin{array}{c}0.012^{*} \\
(0.004)\end{array}$ & $\begin{array}{c}0.010 \\
(0.005)\end{array}$ \\
\hline nonparent $\mathrm{X}$ math score rank & & $\begin{array}{c}-0.006^{*} \\
(0.003)\end{array}$ & & $\begin{array}{r}-0.010 \\
(0.008)\end{array}$ \\
\hline Additional controls (omitted for space) & Yes & Yes & Yes & Yes \\
\hline \multirow[t]{3}{*}{ Number of household-years } & 12,763 & 14,680 & 12,763 & 14,680 \\
\hline & (1) & $(2)$ & (3) & $(4)$ \\
\hline & \multicolumn{2}{|c|}{$\begin{array}{c}\text { housing } \\
\text { expenditure-to-income } \\
\text { ratio }\end{array}$} & \multicolumn{2}{|c|}{$\begin{array}{l}\log (\text { housing } \\
\text { expenditure) }\end{array}$} \\
\hline proportion no reduced-price lunch & $\begin{array}{c}0.065^{*} \\
(0.024)\end{array}$ & $\begin{array}{c}0.078^{*} \\
(0.031)\end{array}$ & $\begin{array}{c}0.319^{*} \\
(0.067)\end{array}$ & $\begin{array}{r}0.299^{*} \\
(0.084)\end{array}$ \\
\hline nonparent $\mathrm{X}$ no reduced-price lunch & & $\begin{array}{r}-0.122^{*} \\
(0.048)\end{array}$ & & $\begin{array}{r}-0.283^{*} \\
(0.132)\end{array}$ \\
\hline Additional controls (omitted for space) & Yes & Yes & Yes & Yes \\
\hline Number of household-years & 12,470 & 14,215 & 12,470 & 14,215 \\
\hline
\end{tabular}

Standard errors are in parentheses.Results from fixed-effects models are based on PSID respondents from 1999 to 2011. Models 1 and 3 include families with children. Models 2 and 4 include all families but exclude respondents who changed parenting status during the analysis period. All models employ survey weights and control for age in years, age squared, years of education, race, marital status, family size, number of rooms in the home, and year indicators. Models 3 and 4 also include a linear and quadratic control for income (logged). The measure of the share of students not eligible for reduced-price lunch is scaled as a proportion rather than a percentage in the tabular results. ${ }^{*} p<0.05$

greater or lesser. We interpret this to mean that higher-SES families are no more willing to stretch themselves financially in order to attain a residence in a better school attendance area.

Models 2 and 4 include households both with and without children, but they exclude respondents who changed parenting status during the analysis period. Households can change parenting status by having a first child, having their youngest child turn 19, or having a child move in (e.g., a stepchild). In each case, these households are probably quite different from households that remain consistently with children or without children. We include an interaction between nonparent household and school desirability. In these models, the coefficient of school desirability represents the predicted effect for households with children, whereas the interaction term shows the difference in the effect for households without children. Again, we find that the effect for households with children remains positive, but the interaction effect is negative (and it is at least marginally significant in seven of the eight models). Consistent with Hypothesis 7, this means that, all else being equal, parents expend more than nonparents for the same improvement in school 
desirability. This suggests that parents are more prone than nonparents to stretch themselves financially in order to realize a given improvement in school attendance areas.

We illustrate this difference in Figure 3, which shows the predicted level for each family, based on coefficients from the full model. Because it is a fixed-effects model, the lines are constrained to intersect when the $x$ axis is zero, but the widening gap between the lines can be interpreted as the amount of increase in the parentnonparent gap for different levels of school desirability. We return to the magnitudes in the discussion below.

In additional analyses, we also specified models with interactions between school desirability and school choice in order to assess whether moves in areas with a greater extent of public-school choice might attenuate the relationship between school desirability and housing expenditure. These analyses were inconclusive (not shown).

Having found above that parents take on greater financial burdens than nonparents to attain a given school quality, the models in Table 3 below test whether, among parents, the relationship between school mobility and expenditures is amplified in higher-inequality areas. This could occur either because the relative price premium of accessing better schools is greater in higher-inequality CZs (which we observed in part 1 above) and/or if the willingness of families to expend more on schools is greater in higher-inequality CZs.

Figure 4 shows the focal interaction estimates of inequality and school desirability from models 1 through 4 of Table 3 . The mostly positive coefficient estimates for the two-way interaction between inequality and school quality suggest that moves to more desirable school attendance areas result in greater increases in housing expenditures in high-inequality CZs. We interpret this to mean that inequality heightens families' willingness to stretch themselves financially in order to gain access to better schools. However, these results were sensitive to different school quality and outcome measures; the association is statistically significant in only three of the four models.

Moreover, like the main effects of school upgrades reported above, the magnitude of the interaction is substantively small. At the 25 th percentile of $\mathrm{CZ}$ inequality, a one-decile upgrade in the test ranking is associated with only a 0.5 -percent increase in housing expenditures, whereas at the 75th percentile, a comparable upgrade is associated with a 1.5-percent increase in housing expenditure. This means that even in a relatively high-inequality $\mathrm{CZ}$, parents who moved from a 50th- to an 80thpercentile school attendance area have a conditional expected housing expenditure increase of less than 5 percent. Given that real mean housing expenditures among parents increased by more than 27 percent from 1999 to 2011 (and only some families are upgrading) intracity moves by parents to access better schools can directly account for only a small portion of the overall growth in housing expenditures among families with children.

In additional analyses, we expanded the sample for the fixed-effects models to also include families who moved between CZs. Interestingly, these specifications yielded substantively very similar estimates for the main effect of school desirability. However, the interaction between CZ-level inequality and school desirability is 
A: Models with school level math score decile rank
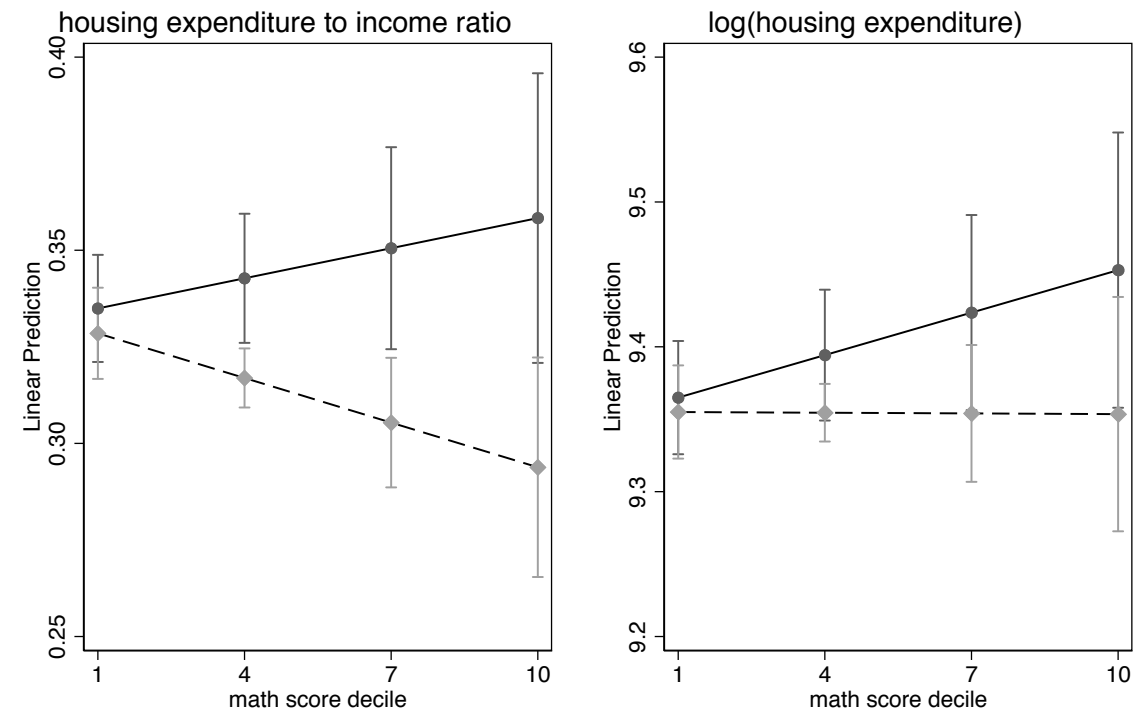

$\longrightarrow$ parent $\quad----$ non-parent

B: Models with school level \% no reduced price lunch
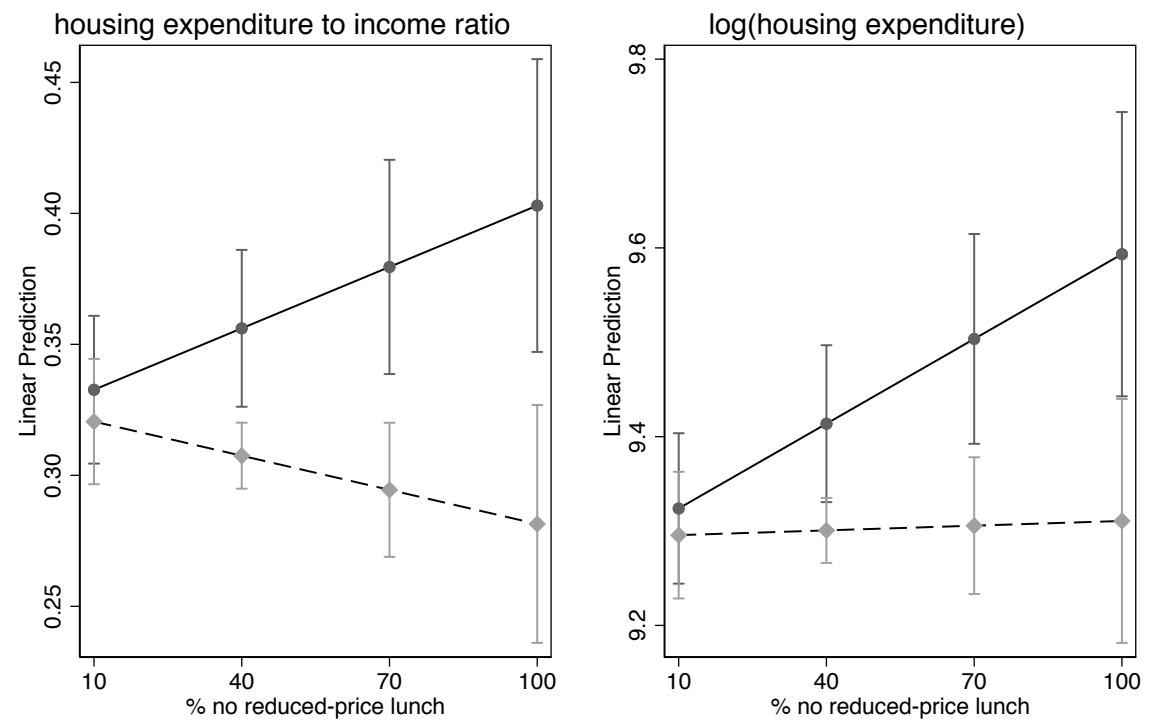

$\longrightarrow$ parent $\quad----$ non-parent

Figure 3: Predicted housing expenditures by parental status. 


\section{Effect of 1 percentile increase in math score rank}
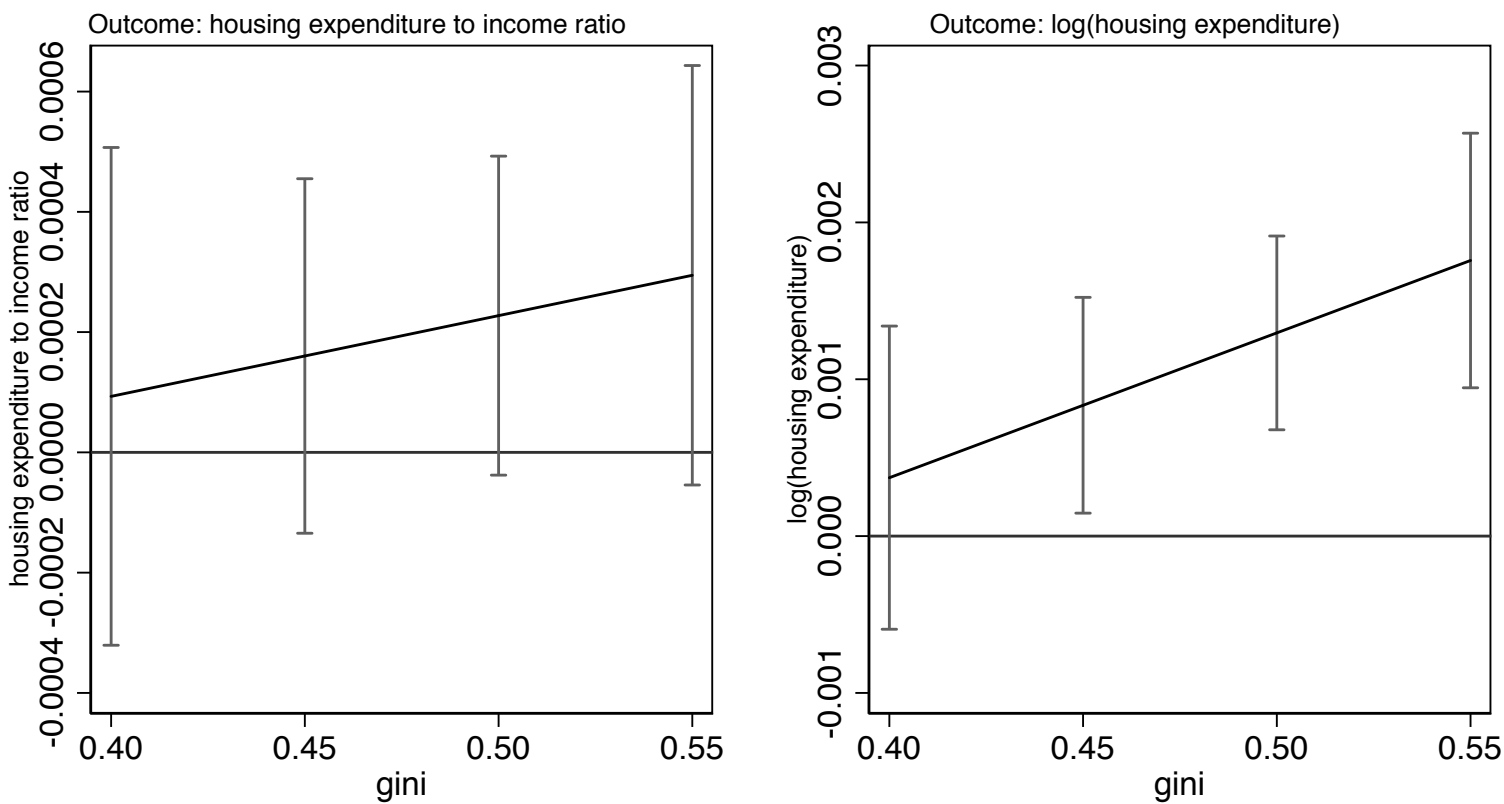

Effect of $1 \%$ decrease in students eligible for reduced lunch
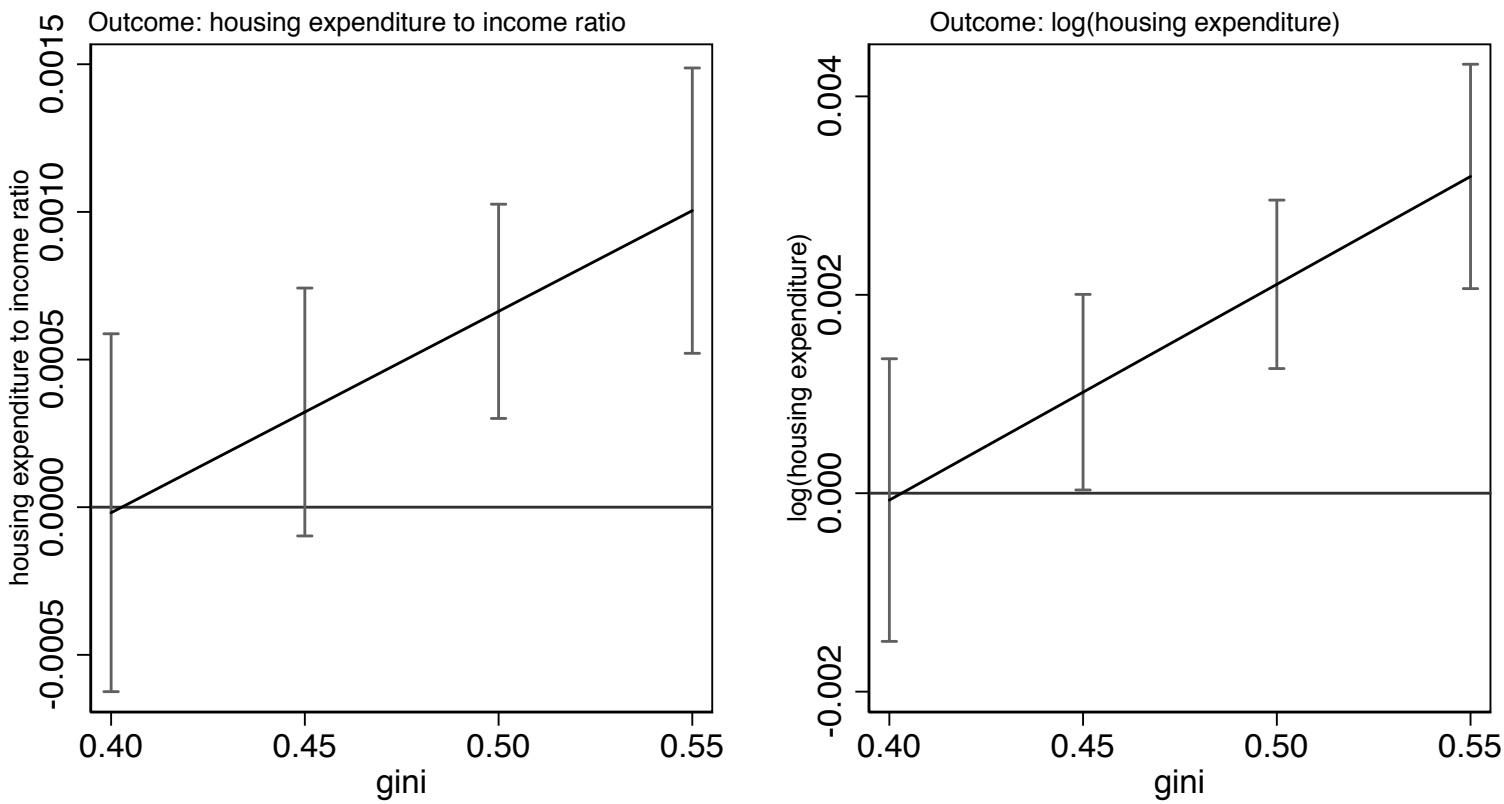

Figure 4: Predicted housing expenditures by income inequality level. 
Table 3: Estimates from fixed-effects models of housing expenditures among parents with school-age children.

\begin{tabular}{|c|c|c|c|c|c|c|c|c|}
\hline & $\begin{array}{c}(1) \\
(\ln ) \mathrm{HE}\end{array}$ & $\begin{array}{c}(2) \\
(\ln ) \mathrm{HE}\end{array}$ & $\begin{array}{c}\text { (3) } \\
\text { HE-Income }\end{array}$ & $\begin{array}{c}(4) \\
\text { HE-Income }\end{array}$ & $\begin{array}{c}(5) \\
(\ln ) \mathrm{HE}\end{array}$ & $\begin{array}{c}(6) \\
(\ln ) \mathrm{HE}\end{array}$ & $\begin{array}{c}(7) \\
\text { HE-Income }\end{array}$ & $\begin{array}{c}(8) \\
\text { HE-Income }\end{array}$ \\
\hline School rank & $\begin{array}{c}-0.003 \\
(0.002)\end{array}$ & & $\begin{array}{c}-0.000 \\
(0.001)\end{array}$ & & $\begin{array}{c}-0.003 \\
(0.002)\end{array}$ & & $\begin{array}{c}-0.000 \\
(0.001)\end{array}$ & \\
\hline Gini x rank & $\begin{array}{r}0.009^{*} \\
(0.004)\end{array}$ & & $\begin{array}{c}0.001 \\
(0.002)\end{array}$ & & $\begin{array}{c}0.009^{*} \\
(0.004)\end{array}$ & & $\begin{array}{c}0.001 \\
(0.002)\end{array}$ & \\
\hline School pay lunch & & $\begin{array}{r}-0.009^{*} \\
(0.003)\end{array}$ & & $\begin{array}{r}-0.003^{*} \\
(0.001)\end{array}$ & & $\begin{array}{r}-0.009^{*} \\
(0.003)\end{array}$ & & $\begin{array}{c}-0.002 \\
(0.001)\end{array}$ \\
\hline Gini x pay lunch & & $\begin{array}{c}0.022^{*} \\
(0.006)\end{array}$ & & $\begin{array}{r}0.007^{*} \\
(0.003)\end{array}$ & & $\begin{array}{c}0.022^{*} \\
(0.007)\end{array}$ & & $\begin{array}{c}0.006^{*} \\
(0.003)\end{array}$ \\
\hline $\mathrm{N}$ rooms in house & $\begin{array}{c}0.070^{*} \\
(0.003)\end{array}$ & $\begin{array}{r}0.071^{*} \\
(0.003)\end{array}$ & $\begin{array}{c}0.013^{*} \\
(0.001)\end{array}$ & $\begin{array}{l}0.013^{*} \\
(0.001)\end{array}$ & $\begin{array}{c}0.073^{*} \\
(0.020)\end{array}$ & $\begin{array}{r}0.077^{*} \\
(0.020)\end{array}$ & $\begin{array}{c}-0.006 \\
(0.008)\end{array}$ & $\begin{array}{r}-0.003 \\
(0.009)\end{array}$ \\
\hline Gini x rooms & & & & & $\begin{array}{c}-0.006 \\
(0.041)\end{array}$ & $\begin{array}{c}-0.013 \\
(0.042)\end{array}$ & $\begin{array}{c}0.039^{*} \\
(0.017)\end{array}$ & $\begin{array}{c}0.035 \\
(0.018)\end{array}$ \\
\hline Not homeowner & $\begin{array}{r}-0.222^{*} \\
(0.015)\end{array}$ & $\begin{array}{r}-0.220^{*} \\
(0.015)\end{array}$ & $\begin{array}{r}-0.026^{*} \\
(0.006)\end{array}$ & $\begin{array}{r}-0.024^{*} \\
(0.006)\end{array}$ & $\begin{array}{r}-0.222^{*} \\
(0.015)\end{array}$ & $\begin{array}{r}-0.220^{*} \\
(0.015)\end{array}$ & $\begin{array}{r}-0.026^{*} \\
(0.006)\end{array}$ & $\begin{array}{r}-0.024^{*} \\
(0.006)\end{array}$ \\
\hline Constant & $\begin{array}{r}6.215^{*} \\
(0.458)\end{array}$ & $\begin{array}{c}6.220^{*} \\
(0.465)\end{array}$ & $\begin{array}{c}0.150 \\
(0.195)\end{array}$ & $\begin{array}{c}0.167 \\
(0.198)\end{array}$ & $\begin{array}{c}6.216^{*} \\
(0.458)\end{array}$ & $\begin{array}{r}6.222^{*} \\
(0.465)\end{array}$ & $\begin{array}{c}0.144 \\
(0.195)\end{array}$ & $\begin{array}{c}0.160 \\
(0.198)\end{array}$ \\
\hline Additional Controls & yes & yes & yes & yes & yes & yes & yes & yes \\
\hline $\begin{array}{l}\text { Year dummies } \\
\text { Observations } \\
\text { Test of Proportionality } \\
\text { Constraint }\end{array}$ & $\begin{array}{c}\text { yes } \\
17,832\end{array}$ & $\begin{array}{c}\text { yes } \\
17,425\end{array}$ & $\begin{array}{c}\text { yes } \\
17,897\end{array}$ & $\begin{array}{c}\text { yes } \\
17,489\end{array}$ & $\begin{array}{c}\text { yes } \\
17,832 \\
\mathrm{f}=3.53 \\
(p=0.06)\end{array}$ & $\begin{array}{c}\text { yes } \\
17,425 \\
\mathrm{f}=7.87 \\
(p=0.005)\end{array}$ & $\begin{array}{c}\text { yes } \\
17,897 \\
\mathrm{f}=0.19 \\
(p=0.66)\end{array}$ & $\begin{array}{c}\text { yes } \\
17,489 \\
\mathrm{f}=0.06 \\
(p=0.81)\end{array}$ \\
\hline
\end{tabular}

Standard errors are in parentheses. Model is estimated on the basis of families with children who remain within the same CZ during the observation period. Additional demographic control variables include marital status, household size, age, education, income, and race. ${ }^{*} p<0.05$

not attained when moving across CZs. We interpret this to mean that families will heighten expenditures to improve relative school rank when moving between regions but no more so when moving from a low-inequality region to a highinequality region.

As a final test, we considered whether greater inequality increases the weighting of schools relative to nonpositional amenities (namely house size) in families' housing expenditure functions. Hypothesis 8 proposed that at higher levels of inequality, willingness to pay for improvements in schools would increase at a comparatively greater rate than willingness to pay for more space. To test this, we added an additional two-way interaction between number of rooms and inequality to the fixed-effect models above. These specifications are shown on the right-hand side of Table 4. To test the difference between the respective interactions, we compared each of these models against a null model in which the effects of schools and house size are constrained to change proportionately across levels of CZ inequality (Buis 2012). Likelihood ratio tests of the proportionality constraints are shown below the unconstrained models in Table 4.

These tests yielded mixed evidence depending on the outcome metric: Models 5 and 6 suggest that where inequality is greater, competition for schools becomes more determinative of changes in log housing expenditures relative to the weight placed on gaining additional rooms (though in one case, the test statistic is only marginally significant). In contrast, models 7 and 8 provide no evidence that inequality heightens the relative weighting of schools over rooms in the housingexpenditure-to-income ratio. Tests of the difference in the interactions indicate that 
Table 4: Summary of hypotheses and results.

\begin{tabular}{|c|c|c|c|}
\hline & Hypothesis & Outcome & Result \\
\hline & Inequality associated with greater housing price premia for schools & & \\
\hline 1 & $\begin{array}{l}\text { Housing price premium for desirable school attendance areas is greater } \\
\text { in higher-inequality CZs }\end{array}$ & $\begin{array}{l}\text { Zip-code } \\
\text { Price }\end{array}$ & Yes \\
\hline 2 & $\begin{array}{l}\text { Housing price premia for desirable school attendance areas grows } \\
\text { larger over time in higher-inequality CZs } \\
\text { Positional Competition Structures: Moves Across School Attendance Areas }\end{array}$ & $\begin{array}{l}\text { Zip-code } \\
\text { Price }\end{array}$ & Null \\
\hline 3 & $\begin{array}{l}\text { Families more likely to upgrade school attendance areas when moving } \\
\text { in unequal CZs }\end{array}$ & $\begin{array}{l}\Delta \text { School } \\
\text { Desirability }\end{array}$ & $\begin{array}{l}\text { No, only for } \\
\text { high SES }\end{array}$ \\
\hline 4 & $\begin{array}{l}\text { High-SES families more likely to upgrade when moving in unequal } \\
\text { CZs }\end{array}$ & $\begin{array}{l}\Delta \text { School } \\
\text { Desirability }\end{array}$ & Yes \\
\hline 5 & $\begin{array}{l}\text { Greater school choice diminishes impetus for high-SES families to } \\
\text { upgrade when moving } \\
\text { Household-Level Financial Consequences of Positional Competition }\end{array}$ & $\begin{array}{l}\Delta \text { School } \\
\text { Desirability }\end{array}$ & $\begin{array}{l}\text { Yes, but only } \\
\text { marginally }\end{array}$ \\
\hline 6 & $\begin{array}{l}\text { Families' willingness to pay more for a given school upgrade is greater } \\
\text { in higher-inequality CZs }\end{array}$ & $\begin{array}{l}\text { Housing } \\
\text { Expenditures }\end{array}$ & $\begin{array}{l}\text { Yes, but only } \\
\text { marginally }\end{array}$ \\
\hline 7 & Parents are willing to pay more than nonparents for desirable schools & $\begin{array}{l}\text { Housing } \\
\text { Expenditures }\end{array}$ & Yes \\
\hline 8 & $\begin{array}{l}\text { Inequality heightens relative weighting of schools in latent expenditure } \\
\text { function }\end{array}$ & $\begin{array}{l}\text { Housing } \\
\text { Expenditures }\end{array}$ & Mixed \\
\hline
\end{tabular}

in only one of the four models can we clearly reject the null hypothesis that the contributions of house size and schools increase proportionately across the Gini distribution. We interpret this as only weak evidence in support of the idea that inequality leads actors to prioritize positional considerations over other types of housing amenities. Table 4 summarizes the hypotheses and results.

\section{Discussion}

In a recent volume entitled Living in a High Inequality Regime, Grusky and MacLean (2016) argue that the social fallout of high inequality is felt primarily through the interaction between inequality and the de facto commodification of quasi-public goods, such as neighborhood schools. The fact that one must pay an ever greater price for a constant relative position is what gives inequality its "teeth" (Grusky and MacLean 2016:44). Although these arguments are frequently invoked, they have not been subjected to careful empirical scrutiny.

Our study has sought to test core empirical implications of inequality-fueled positional competition theories at multiple levels of analysis (Frank 2007). We focused on the schools-housing nexus, the canonical site of positional competition. Our findings lend support to some elements of the theory but also highlight several significant qualifications.

At the zip-code level, we found only partial support for the theory's expectations regarding housing prices: School price premia do tend to be steeper in higher- 
inequality CZs, and overall housing prices grew faster in higher-inequality CZs during the study period. However, within-CZ school price premia did not grow over time, nor did relative premia grow more rapidly in areas with greater inequality at the beginning of the period.

Prior work has suggested that observed cross-sectional associations between inequality and median housing prices and/or housing expenditures could be driven by more intensive competition for schools (Frank 2007; Charles and Lundy 2013). Having decomposed patterns of housing price growth across attendance areas within CZ housing markets, we find little evidence of growing school price premia from 1999 to 2011. Although housing price growth was significantly more pronounced in high-inequality CZs during this period, the relative stability of the school premium in these areas implies that other exogenous factors were operative.

We found more consistent support at the household level, though the magnitudes of association were often modest. Greater CZ inequality is associated with a heightened tendency for higher-SES households to prioritize upgrading schools when moving. Families with children increased their housing expenditures to a greater degree than nonfamilies did in order to attain more desirable school attendance areas, and the costs of upgrading were especially high in less-equal CZs. Families in high-inequality regions exhibit a modestly greater willingness to pay more (relative to their own incomes) for a given improvement in school desirability.

Taken together, these results imply that inequality-fueled positional competition is occurring insofar as greater local inequality does appear to induce the types of behavioral responses identified by the theory. This is especially true for families in the top quintile of the SES distribution. However, the aggregate consequences of these behaviors appear more modest than strong formulations of the PCT would imply: Positional competition for schools within CZs provides relatively little explanatory leverage on the over-time patterns of housing price growth across neighborhoods or housing expenditure growth among families.

The small size of the school effect on expenditures in the fixed-effect model casts doubt on the extent to which competition for schools is driving aggregate growth in households' housing cost burdens. A simple counterfactual exercise, in which we imagine that those families that did upgrade school attendance areas had stayed put, implies that the direct effects of heightened positional competition for schools can account for only a minute share of the overall growth in housing expenditures among families during this period. Of course, one important caveat is that our estimates were based only on intra-CZ moves. This limits our ability to make population-level extrapolations.

Competition for schools does appear to have contributed to residential income sorting among families with children during this period (Owens 2016). Within highinequality CZs, relocating families in the top quintile of the SES distribution tended to upgrade by a full decile in the school test rank distribution, more than twice as much as high-SES households in low-inequality areas and three times as much as families in the bottom two SES quintiles. Heightened income segregation across school attendance areas might help explain the surprisingly modest effects of competition for schools on conditional housing expenditures: The high-SES households that are upgrading also tend to have upward income trajectories, which allow them 
to afford upgrades without excessive increases in their housing expenditure ratios. The effects of positional competition for schools appear to be manifested primarily in increased class sorting (Owens 2016) rather than in expenditure stretching (Frank 2007).

Of course, our failure to detect more pronounced effects could reflect any number of features of our study design. Income inequality in the United States has been growing for nearly four decades, but we examine only a 12-year period from 1999 to 2011. We also rely on cross-sectional measures of inequality. It is possible that over-time trajectories were more responsive to changes in local inequality than they were to starting (1999) levels, although we doubt this to be the case given the minimal change in within-CZ inequality during the 2000s. It is also possible that our results merely capture the steady-state aftermath of transformations that are perceptible only over a longer span of time. Finally, it is worth reiterating that our estimates could be attenuated by the limited spatial granularity of the data, which effectively obscures variation within census tracts and zip codes. Findings from spatial discontinuity studies suggest that families might be pursuing highly localized strategies that our data cannot capture.

Furthermore, some of our (null) findings could be driven by particularities of the historical period. We focused on the 2000s for a mixture of methodological and substantive reasons, namely (1) the significant growth in housing expenditures, (2) the availability of rich data on schools and households, and (3) the still-limited penetration of school-choice programs, which decouple school attendance from residential location. However, the fact that our study coincides with an unprecedented housing market bubble suggests that the gyrations of the housing boom could swamp (and thereby obscure) the underlying processes of interest. Although our analysis seeks to detect how inequality and competition for residential resources interact to shape financial outcomes, a housing market bubble implies that prices and investment behavior had become detached from such "fundamentals." On the other hand, the loose credit conditions and widening credit access that prevailed during the first two-thirds of our study period gave households ready access to the resources with which to compete for residential positions. Hence, we might expect that this period would represent a "most-likely" context for positional competition.

Beyond this, it is important to note several other limitations of analysis. First, commuting-zone income inequality-our key contextual variable-may be correlated with a number of factors that affect housing desirability, such as income segregation, racial segregation, and the amount of geographic spread in the locations of jobs, parks, public transit, and schools themselves. Each of these factors may also heighten competition for the most desirable neighborhoods within a CZ.

Second, we focus in this analysis on a key output measure of school quality: student test scores. Although these data are available to all and increasingly accessible because of online real estate search engines, such as Zillow, we do not know the extent to which parents use this information when deciding which schools they wish for their children to attend. We noted in our discussion of the existing literature that specific evaluative criteria and heuristics with which actors assess school quality are nuanced and variable across groups and contexts (Holme 2002; Johnson and Shapiro 2003; Dougherty et al. 2009). Race, in particular, seems to be a 
factor. Studies have found that white parents perceived a school as being of lower quality and less desirable when the representation of black students was greater (Goyette et al. 2012; Billingham and Hunt 2016) and, most relevant to this analysis, that white parents are especially likely to sort into school districts and neighborhoods with mostly white student populations (Rich 2017). Although beyond the scope of this article, comparing the various factors that contribute to competition for neighborhoods and guide parents' perceptions about the "best" schools for their children is important for future research.

Third, our analysis can only examine movers. Although examining moves is ideal in that it captures the actual behavior of families, it is limited in that it reveals nothing about the preferences of families that do not move. Some families may, for example, wish to move but be unable to do so for financial or other reasons. Although also beyond this article's scope, future work may also seek to integrate the behavior of not moving into analyses of the effects of income inequality, school quality, and housing consumption.

Notwithstanding these limitations, our findings bring important empirical nuance to oft-invoked but untested theories about positional competition for schools as a mechanism by which inequality affects behaviors, consumption, and markets.

More broadly, our findings highlight how the behavioral consequences of positional competition play out differentially across the social class structure. PCT is driven most directly by the upper-middle-class parents who have the ability to participate in this competition. However, the longer-term consequences also extend to the children of those who cannot compete. Because school quality plays a significant role in status attainment (e.g., Duncan and Murnane 2011), our findings highlight a specific link between inequality and reduced future social mobility (Chetty et al. 2014; Grusky and MacLean 2016). Thus, these results have troubling implications for social mobility. Existing research has shown how middle- and upper-class families are making ever larger financial investments in their kids as inequality increases (Schneider et al. 2018). Our work empirically shows yet an additional pathway whereby rising inequality appears to feed itself forward by prompting affluent families to spend in a way that advantages their children. They can compete-sometimes at great financial cost-with other households for the homes that come with access to better schools.

\section{Notes}

1 Logan and colleagues (2018) correct for sampling bias in the American Community Survey and find that there has not been any substantial growth in average residential income segregation nationally since the 1980s.

2 Consistent with this view, the median share of household expenditure on housing was remarkably constant across time and across MSAs during the two decades preceding the housing boom (1980 to 2000; Davis and Ortalo-Magne 2011). This stability was achieved despite rising income inequality and intercity price dispersion by a countervailing trend toward more pronounced sorting by income across cities (Gyourko, Mayer, and Sinai 2013). 
3 Aggregation bias is mitigated by the fact that reliance on district-level measures is disproportionately confined to smaller districts, whereas larger, more heterogeneous districts are more likely to report school-level attendance boundary linkages (including 19 of the 20 largest school districts). The median size (in terms of census tracts) of districts for which we lack school-level linkages is 10 census tracts, whereas the median size of districts for which we have school-level linkages is 59 tracts.

\section{References}

Altintas, Evrim. 2016. “The Widening Education Gap in Developmental Child Care Activities in the United States, 1965-2013." Journal of Marriage and Family 1:26-42. https://doi. org/10.1111/jomf. 12254 .

Autor, David, and David Dorn. 2013. "The Growth of Low Skill Service Jobs and the Polarization of the U.S. Labor Market." American Economic Review 5:1553-97. https: //doi.org/10.1257/aer.103.5.1553.

Bertrand, Marianne, and Adair Morse. 2016. "Trickle-Down Consumption." Review of Economics and Statistics 98:863-79. https : //doi.org/10.1162/rest_a_00613.

Billingham, Chase M., and Matthew O. Hunt. 2016. "School Racial Composition and Parental Choice: New Evidence on the Preferences of White Parents in the United States." Sociology of Education 2:99-117. https://doi .org/10.1177/0038040716635718.

Black, Sandra. 1999. “Do Better Schools Matter? Parental Valuation of Elementary Education." The Quarterly Journal of Economics 114:577-99. https://doi.org/10.1162/ 003355399556070.

Black, Sandra E., and Stephen Machin. 2011. "Housing Valuations of School Performance." Handbook of the Economics of Education 3:485-519. https://doi .org/10.1016/ b978-0-444-53429-3.00010-7.

Bruch, Elizabeth E., and Robert D. Mare. 2001. "Spatial Inequality, Neighborhood Mobility, and Residential Segregation." California Center for Population Research Working Paper Series.

Buis, Maarten L. 2012. “The Composition of Family Background: The Influence of the Economic and Cultural Resources of Both Parents on the Offspring's Educational Attainment in the Netherlands between 1939 and 1991." European Sociological Review 3:593-602. https://doi.org/10.1093/esr/jcs009.

Charles, Maria, and Jeffrey D. Lundy. 2013. “The Local Joneses: Household Consumption and Income Inequality in Large Metropolitan Areas." Research in Social Stratification and Mobility 34:14-29. https://doi .org/10.1016/j.rssm.2013.08.001.

Chetty, Raj, Nathaniel Hendren, Patrick Kline, and Emmanuel Saez. 2014. "Where Is the Land of Opportunity? The Geography of Intergenerational Mobility in the United States." Quarterly Journal of Economics 4:1553-623. https://doi .org/10.1093/qje/qju022.

Clapp, John A., Anupam Nanda, and Stephen L. Ross. 2008. "Which School Attributes Matter? The Influence of School District Performance and Demographic Composition on Property Values." Journal of Urban Economics 63:451-66. https://doi .org/10.1016/j. jue.2007.03.004.

Corcoran, Sean P., and William N. Evans. 2008. "Equity, Adequacy, and the Evolving State Role in Education Finance." Pp. 332-57 in Handbook of Research in Education Finance and Policy, edited by H. F. Ladd and M. E. Goertz. New York, NY: Routledge. https : //doi.org/10.4324/9780203961063. ch19. 
Davis, Morris A., and François Ortalo-Magné. 2011. "Household Expenditures, Wages, Rents." Review of Economic Dynamics 14:248-61. https://doi .org/10.1016/j.red. 2009. 12.003.

Domina, Thurston, Nikolas Pharris-Ciurej, Andrew M. Penner, Emily K. Penner, Quentin Brummet, Sonya R. Porter, and Tanya Sanabria. 2018. "Is Free and Reduced-Price Lunch a Valid Measure of Educational Disadvantage?" Educational Researcher 47:539-55. https://doi .org/10.3102/0013189x18797609.

Dougherty, Jack, Jeffrey Harrelson, Laura Maloney, Drew Murphy, Russell Smith, Michael Snow, and Diane Zannoni. 2009. "School Choice in Suburbia: Test Scores, Race, and Housing Markets." American Journal of Education 115:523-48. https : //doi .org/10 . 1086/ 599780.

Duncan, Greg, and Richard Murnane. 2011. "Introduction: The American Dream, Then and Now." Pp. 3-23 in Whither Opportunity: Rising Inequality, Schools, and Children's Life Chances, edited by R. Murnane and G. Duncan. New York, NY: Russell Sage Foundation Press. https://doi.org/10.1080/15582159.2013.759847.

Fligstein, Neil, Orestes P. Hastings, and Adam Goldstein. 2017. "Keeping up with the Joneses: How Households Fared in the Era of High Income Inequality and the Housing Price Bubble, 1999-2007." Socius 3:1-15. https://doi.org/10.31235/osf .io/jgsxq.

Frank, Robert. 2007. Falling Behind: How Rising Inequality Harms the Middle Class. Berkeley, CA: University of California Press. https : //doi .org/10.1007/s10602-007-9033-1.

Frank, Robert, Adam Seth Levine, and Oege Dijk. 2014. "Expenditure Cascades." Review of Behavioral Economics 1:10-1561.

Goyette, Kimberly, John Iceland, and Elliot Weininger. 2014. “Moving for the Kids: Examining the Influence of Children on White Residential Segregation." City and Community 13:158-78. https://doi.org/10.1111/cico.12058.

Goyette, Kimberly A., Danielle Farrie, and Joshua Freely. 2012. "This School's Gone Downhill: Racial Change and Perceived School Quality among Whites." Social Problems 2:155-76. https://doi.org/10.1525/sp.2012.59.2.155.

Grady, Sarah, and Stacey Bielick. 2010. Trends in the Use of School Choice: 1993 to 2007 (NCES 2010-004). Washington, DC: National Center for Education Statistics, National Institute of Education Sciences, U.S. Department of Education. https ://doi .org/10. $1037 /$ e492162006-008.

Grusky, David B., and Alair MacLean. 2016. "The Social Fallout of a High-Inequality Regime." The Annals of the American Academy of Political and Social Science 1:33-52. https : //doi .org/10.1177/0002716215596946.

Gyourko, Joseph, Christopher Mayer, and Todd Sinai. 2013. "Superstar Cities." American Economic Journal: Economic Policy 5:167-99. https://doi.org/10.1257/pol .5.4.167.

Heckman, James J. 1976. “The Common Structure of Statistical Models of Truncation, Sample Selection and Limited Dependent Variables and a Simple Estimator for Such Models." Annals of Economic and Social Measurement 5:475-92.

Holme, Jennifer Jellison. 2002. "Buying Homes, Buying Schools: School Choice and the Social Construction of School Quality." Harvard Educational Review 2:177-206. https : //doi.org/10.17763/haer.72.2.u6272x676823788r.

Johnson, Heather Beth, and Thomas M. Shapiro. 2003. "Good Neighborhoods, Good Schools: Race and the Good Choices." Pp 173-88 in White Out: The Continuing Significance of Racism, edited by A. Doan and E. Bonilla-Silva. Abingdon, United Kingdom: Routledge. 
Kimelberg, Shelley McDonough. 2014. "Beyond Test Scores: Middle-Class Mothers, Cultural Capital, and the Evaluation of Urban Public Schools." Sociological Perspectives 57:208-28. https://doi.org/10.1177/0731121414523398.

Kornrich, Sabino. 2016. "Inequalities in Parental Spending on Young Children: 1972 to 2010." AERA Open 2:1-12. https://doi .org/10.1177/2332858416644180.

Kornrich, Sabino, and Frank Furstenberg. 2013. “Investing in Children: Changes in Parental Spending on Children, 1972-2007." Demography 1:1-23. https://doi.org/10.1007/ s13524-012-0146-4.

Lareau, Annette, and Kimberly Goyette, eds. 2014. Choosing Homes, Choosing Schools. New York, NY: Russell Sage Foundation. https://doi .org/10.17763/0017-8055.85.2.279.

Lieberson, Stanley, and Joel Horwich. 2008. "Implication Analysis: A Pragmatic Proposal for Linking Theory and Data in the Social Sciences" Sociological Methodology 38:1-50. https://doi.org/10.1111/j.1467-9531.2008.00199.x.

Logan, John R., Andrew Foster, Jun Ke, and Fan Li. 2018. “The Uptick in Income Segregation: Real Trend or Random Sampling Variation?" American Journal of Sociology 124:185-222. https://doi.org/10.1086/697528.

Logan, John R., Elisabeta Minca, and Sinem Adar. 2012. “The Geography of Inequality: Why Separate Means Unequal in American Public Schools." Sociology of Education 85:287-301. https://doi.org/10.1177/0038040711431588.

Moss, David, Anant Thaker, and Howard Rudnick. 2013. "Inequality and Decision Making: Imagining a New Line of Inquiry." Working Paper 13, Harvard Business School. https : //doi.org/10.2139/ssrn.2284341.

Murnane, Richard J., and Sean F. Reardon. 2018. "Long-term Trends in Private School Enrollments by Family Income." AERA Open 1:1-24. https://doi .org/10.3386/w23571.

Neckerman, Kathryn M., and Florencia Torche. 2007. "Inequality: Causes and Consequences." Annual Review of Sociology 33:335-57. https://doi .org/10.1146/annurev . soc.33.040406.131755.

Nelson, Margaret. K. 2010. Parenting out of Control: Anxious Parents in Uncertain Times. New York, NY: New York University Press. https://doi .org/10.1086/658073.

Owens, Ann. 2016. “Inequality in Children's Contexts Income Segregation of Households with and without Children." American Sociological Review 3:549-74. https : //doi .org/ 10.1177/0003122416642430.

Owens, Ann, Sean F. Reardon, and Christopher Jencks. 2014. "Trends in School Economic Segregation, 1970 to 2010." Working Paper, Center for Education Policy Analysis, Stanford University.

Payne, Brian Keith, Jaszmin L. Brown-Iannuzzi, and Jason W. Hannay. 2017. "Economic Inequality Increases Risk Taking." Proceedings of the National Academy of Sciences 114:46438. https://doi.org/10.1073/pnas.1616453114.

Piketty, Thomas, and Emmanuel Saez. 2003. "Income Inequality in the United States, 1913-1998." Quarterly Journal of Economics 118:1-41. https://doi.org/10.1162/ 00335530360535135.

Reardon, Sean F., and Kendra Bischoff. 2011. "Income Inequality and Income Segregation." American Journal of Sociology 4:1092-153. https://doi .org/10.1086/657114.

Rhodes, Anna, and Stefanie DeLuca. 2014. "Residential Mobility and School Choice among Poor Families." Pp. 137-66 in Choosing Homes, Choosing Schools, edited by A. Lareau and K. Goyette. New York, NY: Russell Sage Foundation. https://doi .org/10.1086/682205. 
Rich, Peter. 2017. "Race, Resources, and Test Scores: What Schooling Characteristics Motivate the Housing Choices of White Parents?" Working Paper, Cornell University.

Rich, Peter M., and Jennifer L. Jennings. 2015. "Choice, Information, and Constrained Options: School Transfers in a Stratified Educational System." American Sociological Review 5:1069-98. https://doi.org/10.1177/0003122415598764.

Rivera, Lauren, and Michèle Lamont. 2012. “Price vs. Pets, Schools vs. Styles: The Residential Priorities of the American Upper-Middle Class." Presented at the Meeting of the Eastern Sociological Society, New York, NY.

Sampson, Robert J. 2008. "Moving to Inequality: Neighborhood Effects and Experiments Meet Social Structure." American Journal of Sociology 114:189-231. https ://doi .org/10. $1086 / 589843$.

Schneider, Daniel, Orestes P. Hastings, and Joe LaBriola. 2018. "Income Inequality and Class Divides in Parental Investments." American Sociological Review 83:475-507. https: //doi.org/10.1177/0003122418772034.

Schwartz, Mary, and Ellen Wilson. 2008. Who Can Afford To Live in a Home?: A Look at Data from the 2006 American Community Survey. Suitland, MD: U.S. Census Bureau.

Survey Research Center. 2015. "Panel Study of Income Dynamics restricted use data." 2015. University of Michigan Institute for Social Research. https ://simba.isr . umich.edu/ restricted/docs/NationalCenterEducation/ipeds75_15int-ro.pdf.

Tolbert, Charles M., and Molly Sizer. 1996. US Commuting Zones and Labor Market Areas: A 1990 Update. ERS Staff Paper Number 9614. Washington, DC: Economic Research Service, Rural Economy Division, U.S. Department of Agriculture.

Weininger, Elliot. B. 2014. "School Choice in an Urban Setting." Pp. 268-94 in Choosing Homes, Choosing Schools, edited by A. Lareau and K. Goyette. New York, NY: Russell Sage Foundation. https://doi.org/10.17763/0017-8055.85.2.279.

Yamaguchi, Kazuo. 2002. "Regression Models with Parametrically Weighted Explanatory Variables." Sociological Methodology 32:219-45. https://doi .org/10.1111/1467-9531. 00116.

Zillow. 2014. Home Value Index [machine-readable data file]. Seattle, WA: Zillow Group.

Acknowledgments: The authors are grateful for helpful suggestions from Marianne Bertrand, Neil Fligstein, Kevin McKee, Ann Owens, Peter Rich, participants at the Tobin Project Conference on Inequality and Decision Making, and the editors of Sociological Science. This research was partially supported by funding from the Tobin Project. The first author was also supported by the Robert Wood Johnson Foundation. Collection of the PSID data used in this study was partly supported by the National Institutes of Health (grants R01 HD069609 and R01 AG040213) and the National Science Foundation (awards SES 1157698 and 1623684).

Adam Goldstein : Departments of Sociology and Public Affairs, Princeton University. E-mail: amg5@princeton.edu.

Orestes P. Hastings: Department of Sociology, Colorado State University. E-mail: Pat.Hastings@colostate.edu. 